\title{
PENGEMBANGAN LEMBAR KERJA PESERTA DIDIK BERBASIS ETNOMATEMATIKA PADA MATEI SEGITIGA DAN SEGIEMPAT
}

\author{
Rewatus,A. ${ }^{1}$, Leton,S.I ${ }^{2}$, Fernandez, A.J. ${ }^{3}$, Suci N.M ${ }^{4}$ \\ ${ }^{1,2,3}$ Pendidikan Matematika, Universitas Katolik Widya Mandira, Jl.AYani No 50-52 Kupang \\ ${ }^{4}$ SMPK Sta. Maria Asumta, Jl. Kota Baru, Kupang \\ letonsamuel@unwira.ac.id
}

\begin{abstract}
This research aims to produce ethnomathematics-based student worksheet products of good quality on the material rectangular and triangular. To find out the quality of the learner's activities sheet produced in the three aspects of that is validity, practicality, and effectiveness. The method used in this study is research and development, with the 4-D model development which is modified into 3 stages namely define, design, and develop. The instrument used to measure the quality of student worksheets was a validation questionnaire to measure validity, interviews, and teacher questionnaire responses and student responses to measure practicality and test to measure effectiveness. The result of this study shown the quality of the worksheet of learners meets the valid criteria with an overall average score of 4,8. and the quality of the learner's worksheet meets the practicality criteria with an overall score of 4,73 . And the percentage of student completeness test with a score of $77,7 \%$ meets the effectiveness criteria. Thus the development of ethnomatemics-based LKPD on rectangular and triangular material is of good quality and can be used in learning mathematics.
\end{abstract}

Keywords:Ethnomathematic; Worksheet;Rectangle; Triangular

Penelitian ini bertujuan untuk menghasilkan produk Lembar Kerja Peserta Didik (LKPD) berbasis Etnomatematika yang berkualitas baik pada materi Segiempat dan Segitiga. Untuk mengetahui kualitas dari LKPD yang dihasilkan dilihat dari tiga aspek yaitu kevalidan, kepraktisan dan keefektifan. Metode yang digunakan dalam penelitian ini yaitu research and development $(R \& D)$ dengan model pengembangan four-D(4D) yang dimodifikasi menjadi 3D tahap yaitu define, design, dan develop. Instrumen yang digunakan untuk mengukur kualitas LKPD yaitu angket lembar validasi untuk mengukur kevalidan, wawancara, angket respon guru dan respon peserta didik untuk mengukur kepraktisan, dan tes untuk mengukur keefektifan.Hasil dari penelitian ini menunjukkan kualitas LKPD memenuhi kriteria kevalidan dengan skor rata - rata keseluruhan sebesar 4,8 dan kualitas LKPD memenuhi kriteria kepraktisan dengan skor rata - rata keseluruhan sebesar 4,73 sertapersentase ketuntasan tes peserta didik sebesar 77,7\% memenuhi kriteria keefeektifan.Dengan demikian Pengembangan LKPD berbasis Etnomatematika pada materi segiempat dan segitiga berkualitas baik dan dapat digunakan dalam pembelajaran matematika.

Kata kunci:LKPD, Etnomatematika, Segiempat, Segitiga

\section{PENDAHULUAN}

Matematika memiliki peran yang sangat penting dalam kehidupan sehari-hari, dimana hampir semua yang ada di sekitar kita berkaitan dengan matematika termasuk juga dengan budaya masyarakat. Matematika sangat erat kaitannya dengan kehidupan sehari-hari dan budaya masyarakat (Darmayasa, Wahyudin, \& Mulyana, 2018).Pelajaran matematika yang dipelajari peserta didik di sekolah terkadang berbeda dengan masalah matematik yang ditemui dalam kehidupan sehari-hari, menyebabkan sulitnya peserta didik menghubungkan keterkaitan antara konsep matematik dan permasalahan pada budaya (Agustini, Leton, \& Fernandez, 2019). Bila anak belajar matematika terpisah dari pengalaman mereka sehari-hari maka anak akan cepat lupa dan tidak dapat mengaplikasikan matematika (Mustamin, 2017). Pembelajaran matematika hendaknya mengaitkan pengalaman sehari-hari peserta didik untuk mendapatkan pemahaman yang lebih baik dan strategi untuk menciptakan lingkungan belajar dan pengalaman belajar yang mengintegrasikan budaya sebagai bagian dari proses pembelajaran yaitu pembelajaran berbasis budaya. Salah satunya dengan 
memanfaatkan pendekatan Etnomatematika.(Wahyuni, Aji, Tias, \& Sani, 2013). Negara Jepang dan Tionghoa berhasil karena mereka menerapkan Etnomatematika dalam pembelajaran matematika (Prabawati, Yanto, \& Mandasari, 2019).

Kesulitan peserta didik dalam menghubungkan matematika dengan kehidupan nyata menjadikan faktor utama pentingnya pembelajaran berbasis budaya yaitu menggunakan pendekatan Etnomatematika. Pembelajaran berbasis budaya adalah pembelajaran yang memungkinkan guru dan peserta didik berpartisipasi aktif berdasarkan budaya yang sudah mereka kenal, sehingga dapat diperoleh hasil belajar yang optimal (Ayuningtyas \& Setiana, 2019). Selain itu agar peserta didik mengenal dan mempertahankan budaya lokal yang ada di sekitar masyarakat. Budaya adalah suatu hal yang tidak bisa kita hindari dalam kehidupan sehari-hari, karena budaya adalah satu kesatuan yang menyeluruh dari beragam perwujudan prilaku dari masyarakat (Pertiwi \& Budiarto, 2020). Sekarang ini bidang Etnomatematika, yaitu matematika yang tumbuh dan berkembang dalam masyarakat dan sesuai dengan kebudayaan setempat, dapat digunakan sebagai pusat proses pembelajaran dan metode pengajaran, walaupun masih relatif baru dalam dunia Pendidikan (Marsigit, 2016).Dengan demikian, agar terjadi belajar bermakna maka guru harus selalu berusaha mengetahui dan menggali konsep-konsep yang telah dimiliki peserta didik dan membantu memadukannya secara harmonis konsep-konsep tersebut dengan pengetahuan baru yang akan diajarkan dan mengaitkan antara materi yang diajarkan dengan situasi dunia nyata peserta didik dan mendorong peserta didik membuat hubungan antara pengetahuan yang dimilikinya dengan penerapandalam kehidupan mereka sebagai anggota keluarga dan masyarakat (Purnamasari \& Lestari, 2017). Dengan kata lain guru adalah fasilisator, selain itu guru harus mampu mengembangkan bahan ajar yang digunakan agar peserta didik tidak merasa bosan dan jenuh ketika belajar matematika (Susanti Esa, Sukasno, 2017). Cara yang bisa dilakukan guru untuk menciptakan dan mengembangkan bahan ajar antara lain dengan menggunakan pendekatan dalam proses pengembangan bahan ajarnya, yang sesuai dengan materi yang akan disampaikan (Ayuningtyas \& Setiana, 2019). Salah satu jenis bahan ajar yang bisa dikembangkan oleh guru adalah Lembar Kerja Peserta Didik (LKPD).

LKPD memudahkan guru dalam melaksanakan pembelajaran, membantu peserta didik dalam belajar dan memahami materi pembelajaran. Dalam LKPDpeserta didik akanmendapatkan materi, ringkasan, tugas yang berkaitan dengan materi danterdapat arahan untuk memahami materi yang diberikan sehingga akanmembuat peserta didik belajar mandiri (Harionik Yeni \& Yoga, 2018).LKPD berisi panduan bagi peserta didik yang digunakan untuk melakukan kegiatan penyelidikan atau pemecahan masalah LKPD mempunyai pengaruh yang besar dalam pembelajaran, LKPD dapat mendorong proses berpikir peserta didik sehingga memudahkan peserta didik dalam menyelesaikan suatu masalah. Penggunaan LKPD dapat meningkatkan aktivitas belajar peserta didik, mendorong peserta didik mampu bekerja sendiri dan membimbing peserta didik secara baik ke arah pengembangan konsep (Atika \& MZ, 2016).LKPD bertujuan untuk menuntun peserta didik serta 
Pengembangan Lembar Kerja Peserta Didik Berbasis Etnomatematika Pada Matei Segitiga Dan Segiempat, Rewatus,A., Leton,S.I, Fernandez, A.J., Suci N.M

menumbuhkan proses berpikir pada diri peserta didik (Prabawati et al., 2019). Masalahnya adalah bagaimana model LKPD yang berkualitas baik yang dapat digunakan dalam pembelajaran matematika yang memfasilitasi peserta didik didik untuk membangun pemahaman pada materi segiempat dan segitiga. Penelitian ini untuk menghasilkan produk LKPD berbasis Etnomatematika yang berkualitas baik baik pada materi segiempat dan segitiga melalui proses pengembangan four-D (4-D). Etnomatematika yang digunakan pada penelitian ini yaitu studi Etnomatematika pada budaya masyarakat Larantuka.

\section{METODE}

Jenis penelitian ini yaitu penelitian dan pengembangan (research and development) dengan model pengembangan 4-D yang dimodifikasi menjadi 3-D yaitu define, design, dan develop yang mengacu pada alur pengembangan perangkat pembelajaran (Thiangarajan, Sivasailam, \& Dkk, 1974). Model pengembangan 4-D ini yang dimodifikasi menjadi 3-D disebabkan oleh keterbatasan biaya dan waktu dalam proses penelitian. Penelitian ini dilakukan di SMPK St. Maria Asumpta Kupang dengan subyek penelitian kelas VII.bPengumpulan data menggunakan angket, wawancara dan tes.bInstrumen pengumpulan data yaitu angket validasi LKPD untuk mengukur kevalidan produk LKPD, wawancara dan instrumen lembar penilaian guru dan peserta didik untuk mengukur kepraktisan produk LKPD dan tes untuk mengukur keefektifan produk LKPD. Analisis data merujuk pada langkah-langkah 3D yang terdiri atas; define (pendefinisian), design (perancangan), develop (pengembangan). Berikut alur pengembangan model 4-D:

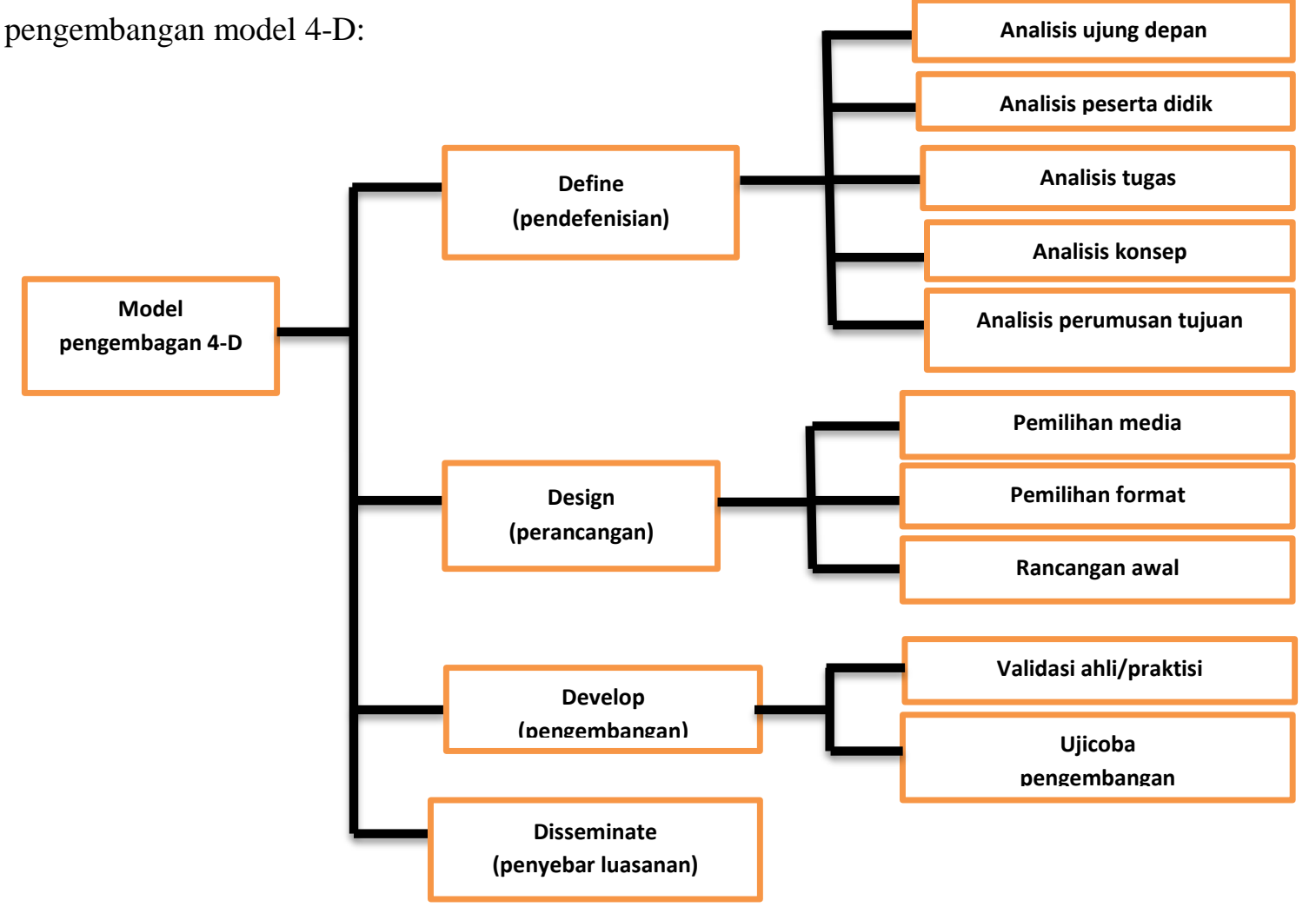

Gambar 1. Prosedur Pelaksanaan Penelitian Pengembangan Model 4D 


\section{HASIL}

Proses pengembangan LKPD berbasis Etnomatematika pada materi Segitiempat dan Segitiga di SMPK St. Maria Assumpta Kupang menggunakan model pengembangan four-D (4-D) yang dimodifikasi menjadi (3-D) terdiri dari 3 tahap yaitu define (pendefinisian), design (perancangan), dan develop (pengembangan). Hasil analisisnya pada masing-masing tahap sebagai berikut:

\section{Tahap define (pendefenisian)}

Pada tahap define (pendefenisian) atau tahap awal pengembangan LKPD dilakukan wawancara terhadap guru mata pelajaran di sekolah tersebut untuk mendapatkan data yang di butuhkan. Tahap ini terdiri dari 5 langka. Hasil analisis data yang diperoleh sebagai berikut: 1) Sekolah tersebut menggunakan kurikulum 2013 dalam kegiatan pembelajaran, namun peserta didik kurang terlibat dalam dalam proses pembelajaran, sehingga hanya terfokus pada guru saja. Hal ini disebabkan oleh kurangnya keaktifan, kesenangan, dan kebiasaan minat belajar peserta didik yang kurang terlihat; 2) Kemampuan intelektual dan kognitif peserta didik seimbang dari yang tinggi, sedang, dan rendah.hal ini diperoleh dari hasil wawancara guru matapelajaran matematika di sekolah tersebut; 3) Kompetensi Dasar yang dicapai peserta didik pada materi Segiempat dan Segitiga pokok bahasan Keliling dan Luas Segiempat dan Segitiga yang terdapat pada RPP di sekolah tersebut; 4) Mengidentifikasi konsep materi segiempat dan segitiga yang di ajarkan dan menyusun dalam peta konsep serta mengetahui standar kompetensi dan kompetensi dasar yang ada sesuai dengan rancangan pelaksanaan pembelajaran (RPP) yang berlaku di sekolah tersebut. Sumber belajar yang digunakan berupa buku Erlangga, internet dan LKPD; 5) Disesuaikan dengan indikator pencapaian kompetensi pada materi segiempat dan segitiga setelah pembelajaran berlangsung dan merangkum hasil dari analisis konsep dan analisis tugas sesuai dengan materi Segiempat dan Segitiga.

\section{Tahap design (perancangan)}

Pada tahap design (perancangan) dibuat rancangan awal LKPD yang sesuai dengan tahap define (pendefenisian). Pemilihan format dilakukan untuk merancang isi pembelajaran, sumber belajar, dan mendapatkan kesesuaian antara gambar dan tulisan yang terdapat dalam LKPD.Dalam pemilihan format diperhatikan juga syarat didaktik, syarat kontruksi, syarat teknis dalam penyusunan LKPD.Pada tahap ini dihasilkan rancangan awal LKPD berbasis Etnomatematika pada materi segiempat dan segitiga. Desain awal LKPD berbasis Etnomatematika dapat dilihat pada Gambar 2.

\section{Tahap pengembangan (develop)}

Pada tahap pengembangan (develop), desain LKPD beserta instrumen diberikan kepada validator yaitu dua dosen pendidikan matematika dan guru matapelajaran SMPK St. Maria Assumpta.Instrumen tersebut diisi oleh validor untuk menilai kevalidan LKPD.Penilaian kevalidan LKPD oleh ketiga validator direvisi sebanyak dua kali.Berikut lembar validasi ahli terhadap LKPD oleh validator dapat dilihat pada Gambar 3 dan 4. 
Pengembangan Lembar Kerja Peserta Didik Berbasis Etnomatematika Pada Matei Segitiga Dan Segiempat, Rewatus,A., Leton,S.I, Fernandez, A.J., Suci N.M
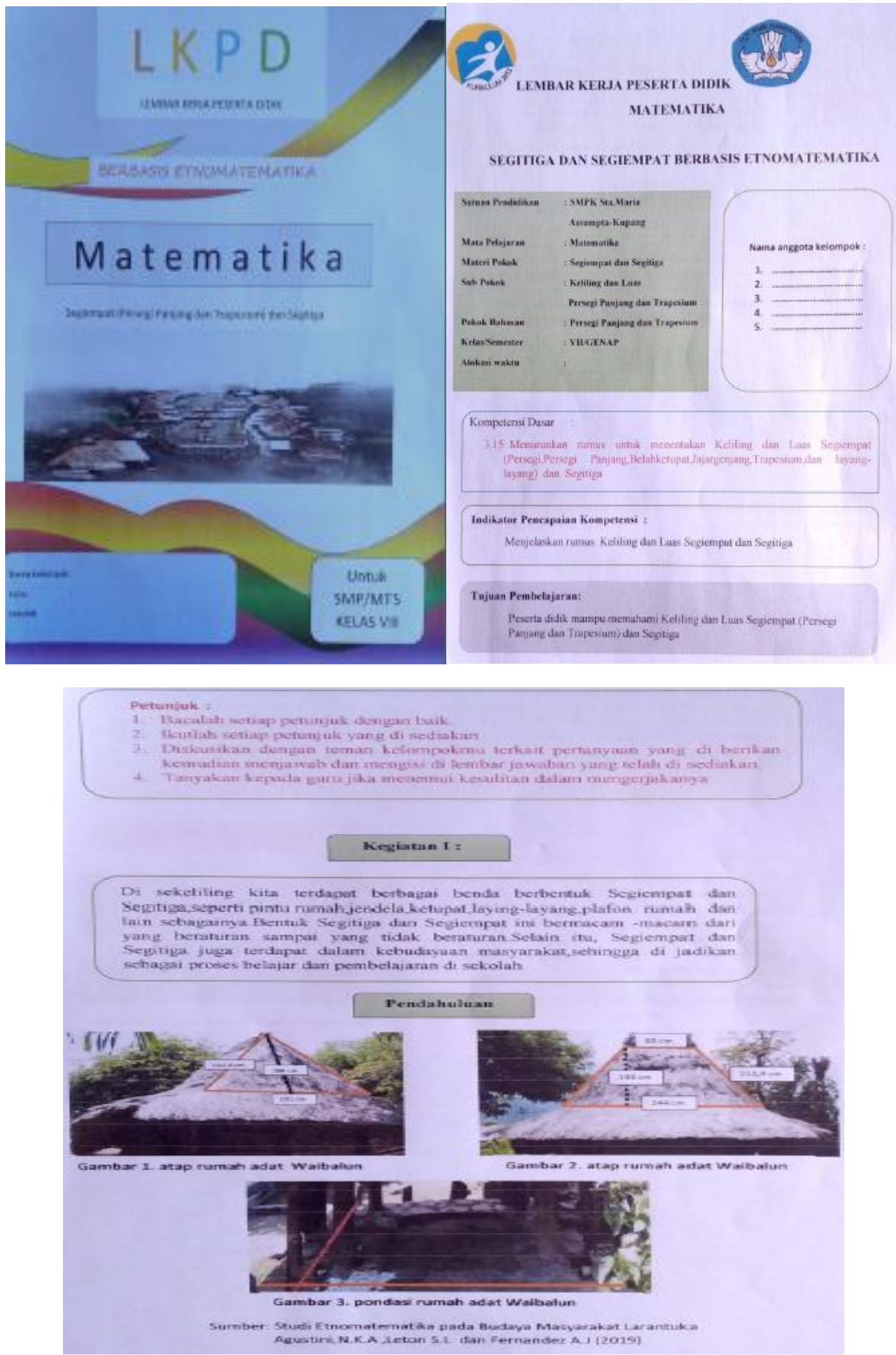

Gambar 2. Desain awal LKPD berbasis Etnomatematik 


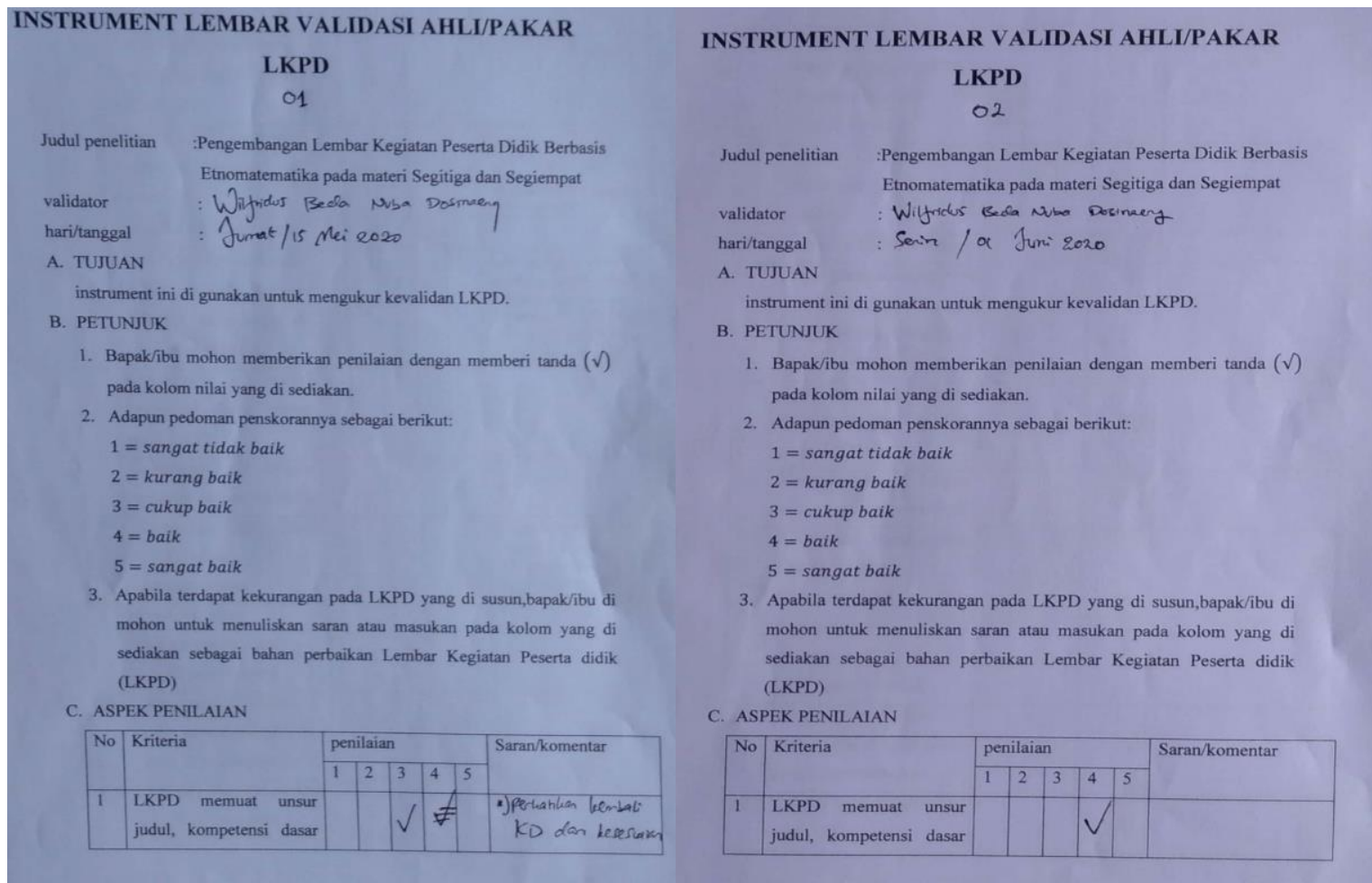

Gambar 2. Lembar Validasi Dari Validator I
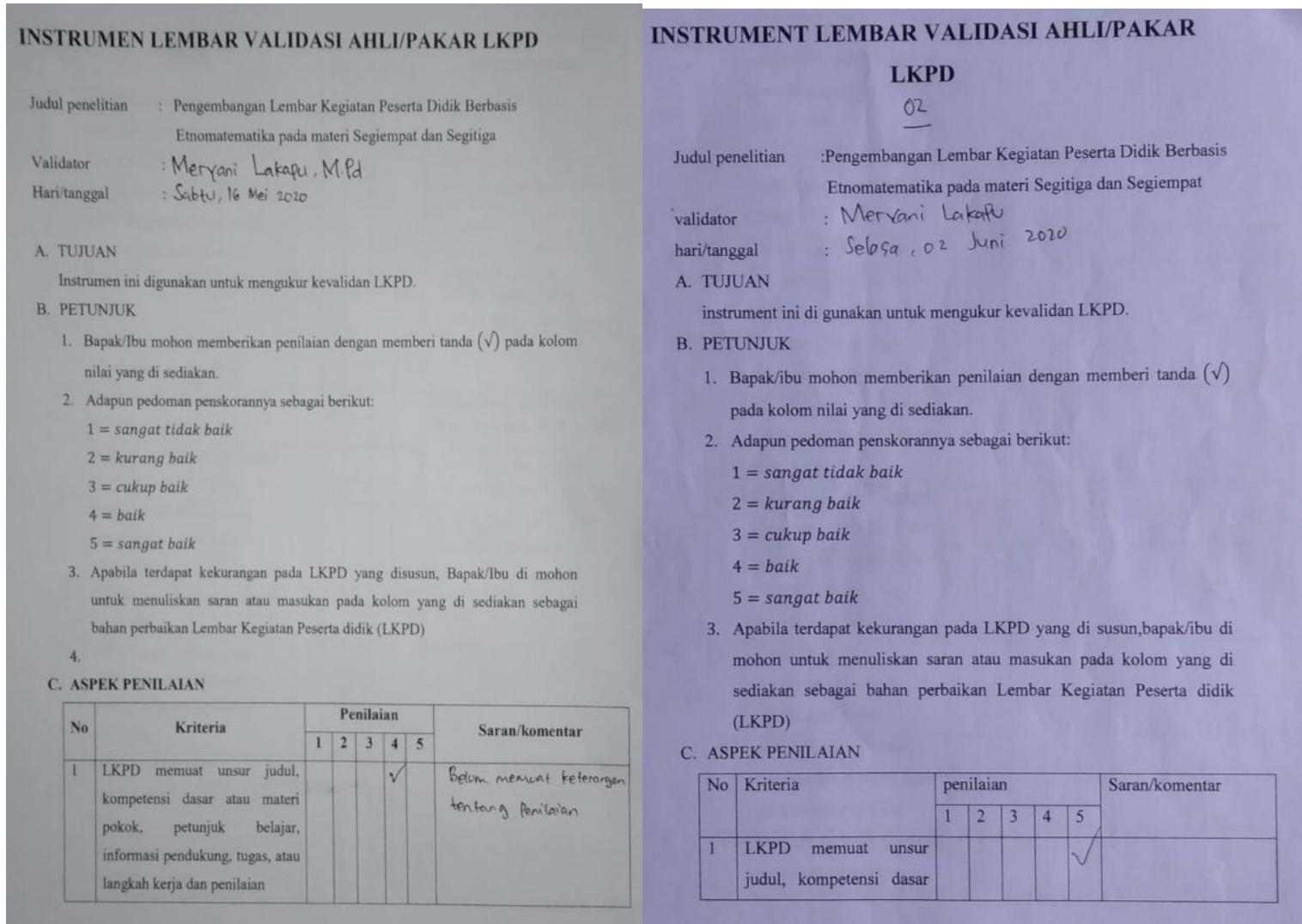

Gambar 3. Lembar Validasi Dari Validator II 


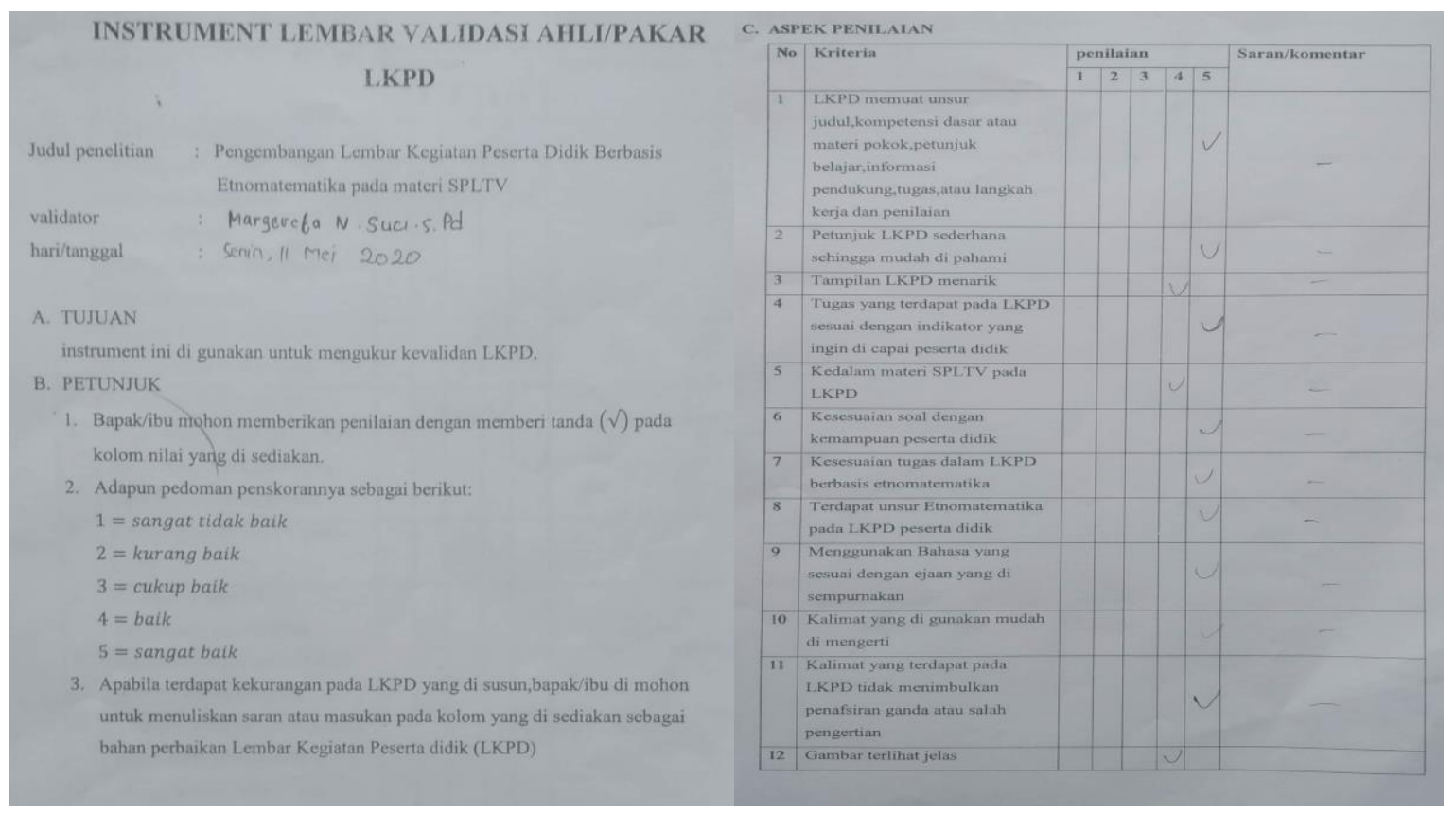

Gambar 4.Lembar Validasi Sebelum dan Sesudah Revisi Dari Validator III

Hasil penilaian kevalidan LKPD setelah direvisi oleh ketiga validator sebagai berikut:Rata - rata hasil keseluruhaan penilaian kevalidan LKPD dari tiga validator terhadap LKPD yang dikembangkan, termasuk dalam kategori valid dengan skor rata - rata sebesar 4,48 sehingga LKPD yang di kembangkan telah memenuhi kriteria kevalidan. Berikut LKPD hasil validasi ahli

Tabel 1.

Hasil penilaian kevalidan LKPD oleh validator

\begin{tabular}{|c|l|ccc|}
\hline \multirow{2}{*}{ No } & \multicolumn{1}{|c|}{ Kriteria } & \multicolumn{3}{c|}{ Penilaian validator } \\
& \multicolumn{1}{|c|}{ 1 } & & 2 \\
\hline 1 & $\begin{array}{l}\text { LKPD memuat unsur judul, kompetensi dasar atau } \\
\text { materi pokok, petunjuk belajar, informasi pendukung, } \\
\text { tugas, atau langkah kerja }\end{array}$ & 4 & 5 & 5 \\
\hline 2 & Petunjuk LKPD sederhana sehingga mudah di pahami & 4 & 4 & 4 \\
\hline 3 & Tampilan LKPD menarik & 5 & 4 & 4 \\
\hline 4 & $\begin{array}{l}\text { Tugas yang terdapat pada LKPD sesuai dengan } \\
\text { indikator yang ingin di capai peserta didik }\end{array}$ & 4 & 4 & 3 \\
\hline 5 & $\begin{array}{l}\text { Mempermudah peserta didik untuk memahami materi } \\
\text { Segiempat dan Segitiga }\end{array}$ & 5 & 4 & 4 \\
\hline 6 & Kesesuaian soal dengan kemampuan peserta didik & 5 & 5 & 5 \\
\hline 7 & $\begin{array}{l}\text { Kesesuaian tugas dalam LKPD berbasis } \\
\text { Etnomatematika }\end{array}$ & 4 & 5 & 4 \\
\hline 8 & Terdapat unsur Etnomatematika pada LKPD tersebut. & 4 & 5 & 5 \\
\hline 9 & $\begin{array}{l}\text { Menggunakan Bahasa yang sesuai dengan ejaan yang } \\
\text { di sempurnakan }\end{array}$ & 5 & 4 & 5 \\
\hline 10 & Kalimat yang di gunakan mudah di mengerti & 5 & 5 & 5 \\
\hline 11 & $\begin{array}{l}\text { Kalimat yang terdapat pada LKPD tidak } \\
\text { menimbulkan penafsiran ganda atau salah pengertian }\end{array}$ & 4 & 4 & 5 \\
\hline
\end{tabular}




\begin{tabular}{|c|l|ccc|}
\hline 12 & Gambar terlihat jelas & 5 & 3 & 5 \\
\hline 13 & Identitas pengguna LKPD (nama, kelas) & 5 & 5 & 5 \\
\hline 14 & Kesesuaian gambar dalam mendukung materi & 5 & 5 & 5 \\
\hline 15 & Menimbulkan aktivitas kreatif peserta didik & 4 & 5 & 3 \\
\hline & Rata-rata & 4,53 & 4,46 & 4,46 \\
\hline
\end{tabular}
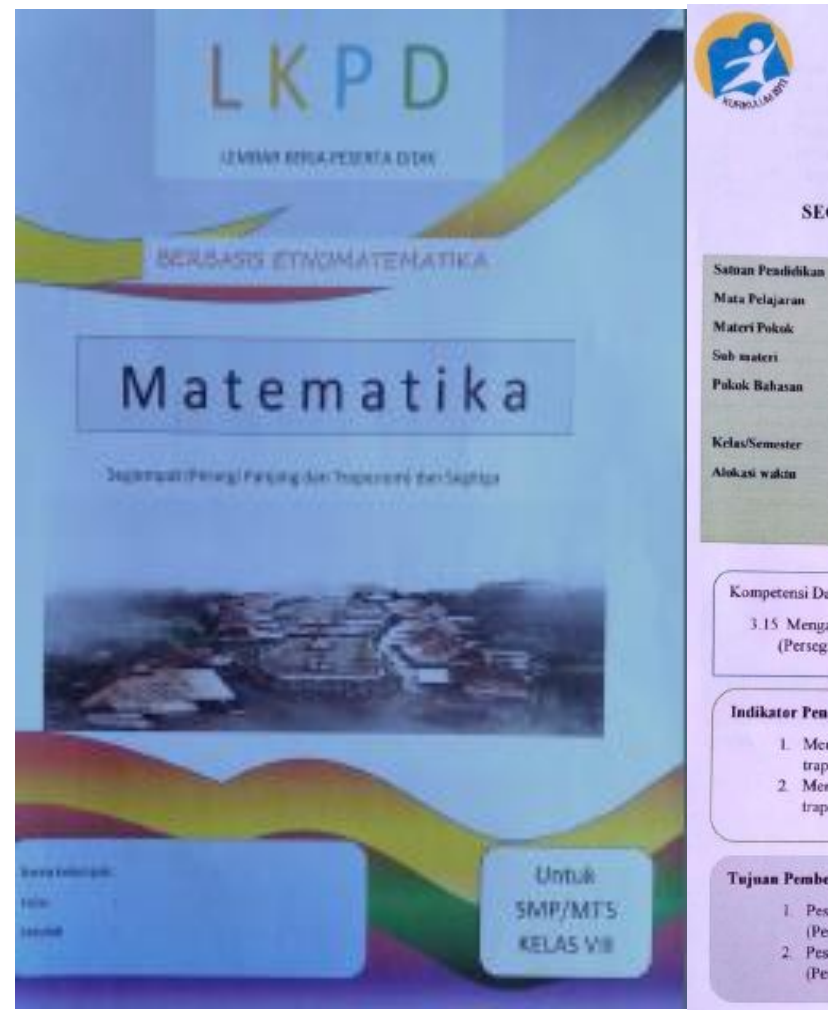

LEMBAR KER.JA PESERTA DIDIK MATEMATIKA

SEGIEMPAT BERBASIS ETNOMATEMATIKA

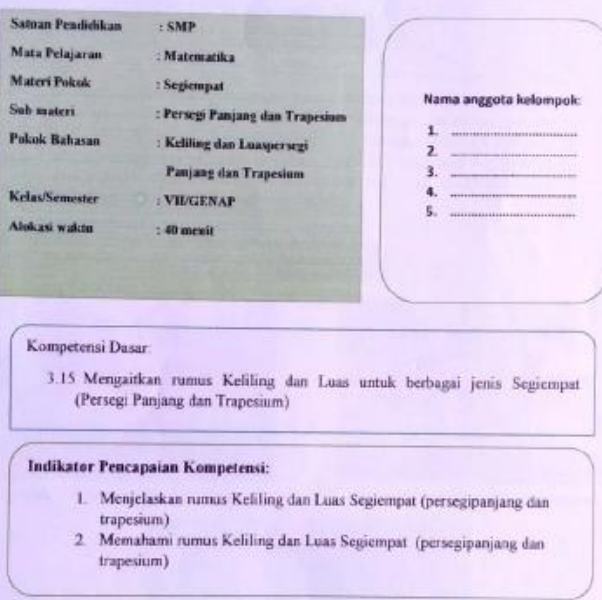

Trjusun Permbelajaran:

1 Peserta didik mainpu menjelaskan numus Ketling dan Luas Segiempa

(Persegr Panjang dan Trapesuan) Peserta didik mampu memahami rumus Keliling dan Leas Segiempat
(Persegi Panjaing dal Trapesum)

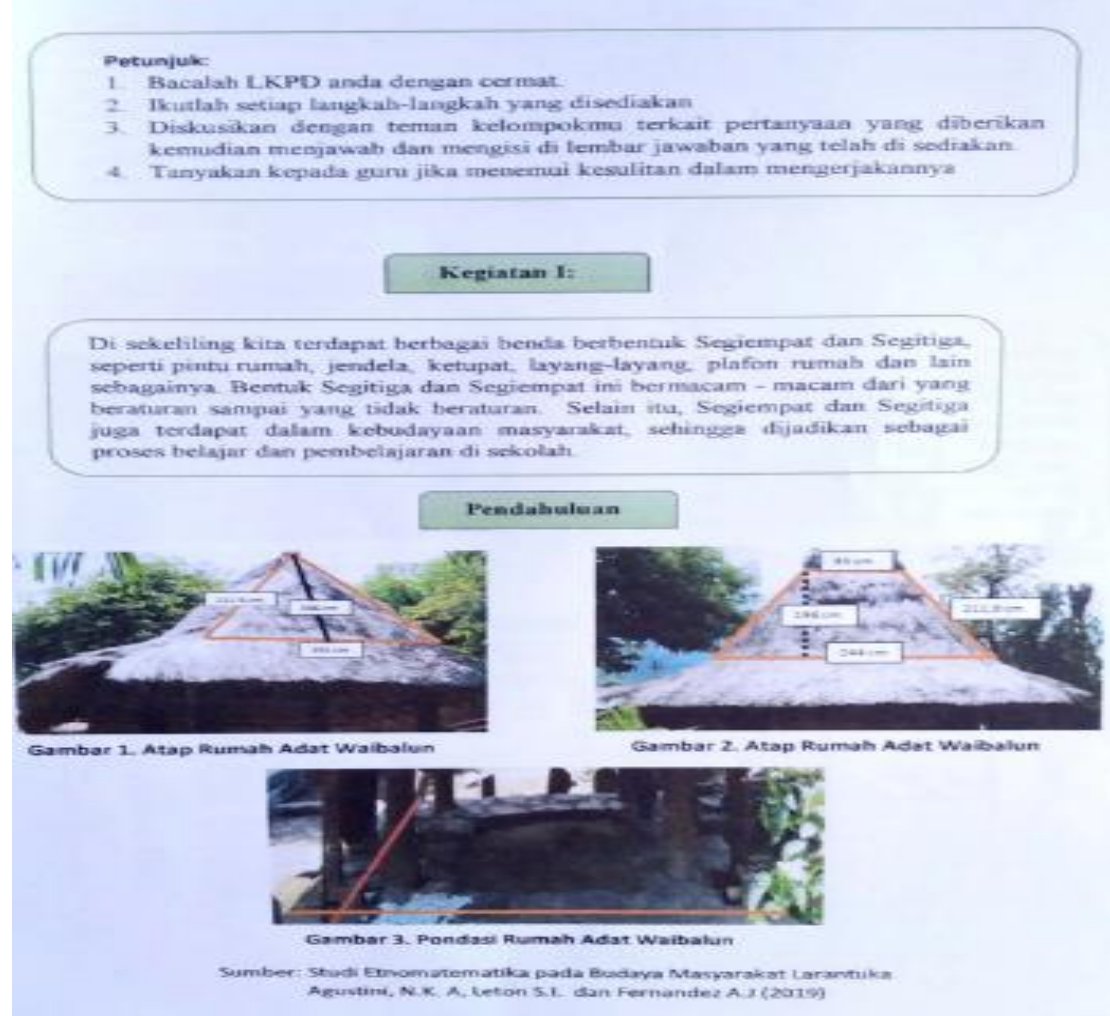

Gambar 5. Desain LKPD hasil revisi ahli 
Pengembangan Lembar Kerja Peserta Didik Berbasis Etnomatematika Pada Matei Segitiga Dan Segiempat, Rewatus,A., Leton,S.I, Fernandez, A.J., Suci N.M

LKPD yang telah memenuhi kriteria kevalidan diberikan kepada guru mata pelajaran untuk mengetahui respon guru terhadap LKPD dan diujicobakan ke peserta didik untuk mengetahui kepraktisan LKPD yang di kembangkan.Pada tahap ini dilakukan uji coba terbatas untuk mengetahui respon peserta didik terhadap LKPD yang di kembangkan. Peserta didik tersebut terdiri dari tiga orang yang di ambil dari satu kelas.Berikut respon guru dan peserta didik terhadap LKPD:

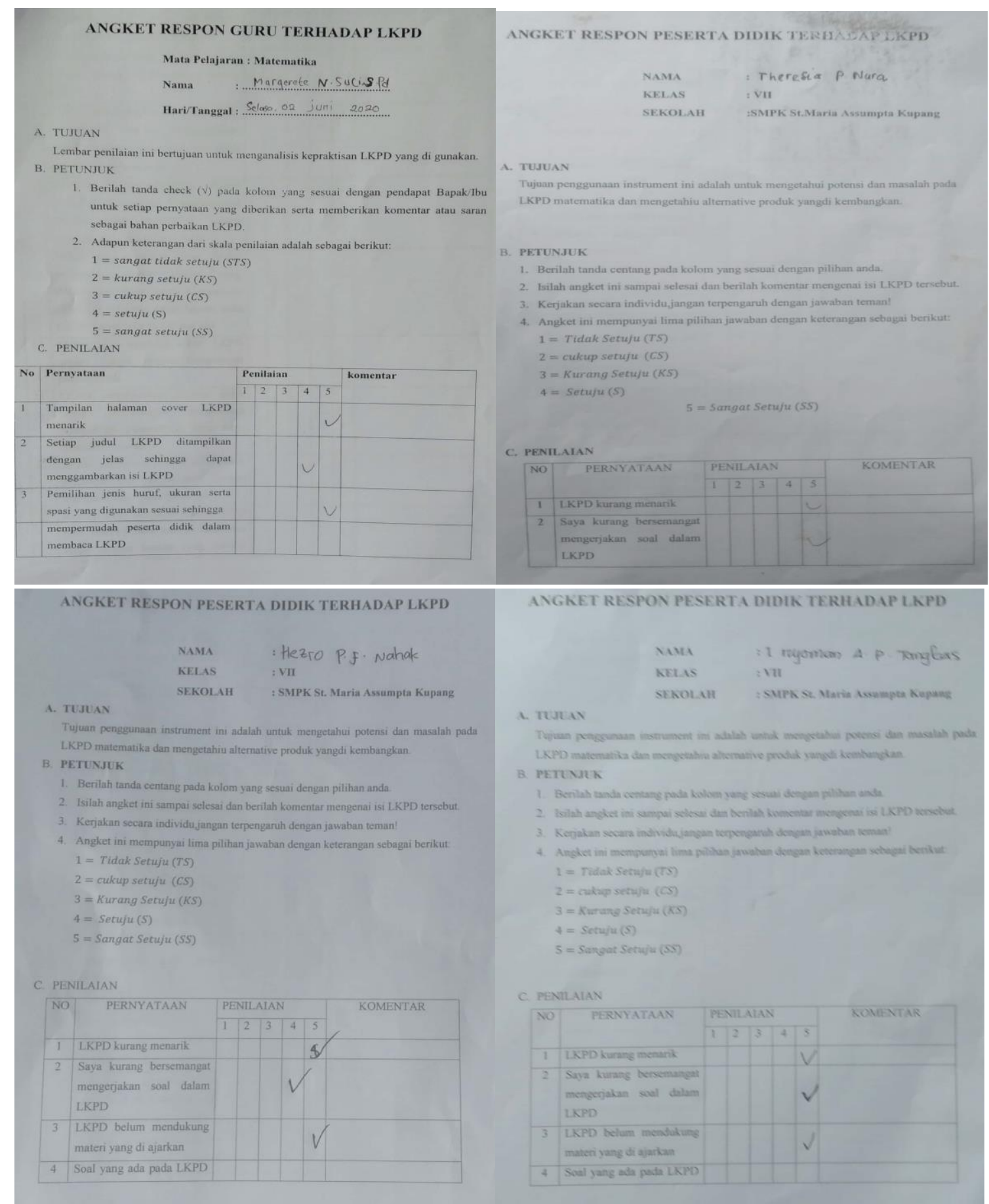

Gambar 6.Angket Respon Guru Dan Peserta Didik Terhadap LKPD

Respon guru terhadap LKPD dengan skor sebesar 4,6 dikategorikan sangat baik dan memenuhi kriteria kepraktisan sehingga tidak perlu direvisi kembali. Respon peserta didik pertama terhadap 
LKPD dengan skor sebesar 4,8 dikategorikan sangat baik dan memenuhi kepraktisan LKPD, sehingga tidak perlu direvisi kembali. Respon peserta didik kedua terhadap LKPD dengan skor sebesar 4,7 dikategorikan sangat baik dan memenuhi kepraktisan LKPD, sehingga tidak perlu direvisi kembali. Respon peserta didik ketiga terhadap LKPD dengan skor sebesar 4,7 dikategorikan sangat baik dan memenuhi kepraktisan LKPD, sehingga tidak perlu direvisi kembali. Berikut penilaian hasil respon peserta didik terhadap LKPD:

Tabel 2.

Penilaian hasil respon peserta didik terhadap LKPD

\begin{tabular}{|c|c|c|c|c|}
\hline \multirow[t]{2}{*}{ No. } & \multirow[t]{2}{*}{ Kriteria } & \multicolumn{3}{|c|}{ Penilaian peserta didik } \\
\hline & & 1 & 2 & 3 \\
\hline 1. & LKPD kurang menarik & 5 & 5 & 5 \\
\hline 2. & $\begin{array}{l}\text { Saya kurang bersemangat mengerjakan soal dalam } \\
\text { LKPD }\end{array}$ & 5 & 4 & 5 \\
\hline 3. & LKPD belum mendukung materi yang di ajarkan & 5 & 5 & 5 \\
\hline 4. & $\begin{array}{l}\text { Soal yang ada pada LKPD ada yang tidak jelas atau } \\
\text { salah }\end{array}$ & 5 & 5 & 4 \\
\hline 5. & $\begin{array}{l}\text { Soal di LKPD tidak sesuai dengan materi yang di } \\
\text { pelajari }\end{array}$ & 5 & 5 & 5 \\
\hline 6. & Gambar LKPD kurang menarik & 5 & 5 & 5 \\
\hline 7. & Gambar pada LKPD kurang mendukung materi & 4 & 5 & 5 \\
\hline 8. & Bahasa dalam LKPD kurang menarik & 5 & 5 & 5 \\
\hline 9. & $\begin{array}{l}\text { Soal - soal pada LKPD tidak sesuai dengan } \\
\text { kemampuan matematika saya }\end{array}$ & 4 & 4 & 4 \\
\hline 10. & $\begin{array}{l}\text { LKPD kurang mendukung saya untuk memahami } \\
\text { pelajaran matematika }\end{array}$ & 5 & 4 & 4 \\
\hline 11. & Saya masih bingung mengerjakan soal pada LKPD & 4 & 5 & 4 \\
\hline 12. & LKPD buram & 5 & 5 & 5 \\
\hline 13. & $\begin{array}{l}\text { Desain, penulisan, dan Bahasa dalam LKPD } \\
\text { matematika begitu menarik }\end{array}$ & 5 & 4 & 5 \\
\hline 14. & $\begin{array}{l}\text { LKPD matematika membuat saya memahami materi } \\
\text { sedikit demi sedikit }\end{array}$ & 5 & 5 & 5 \\
\hline 15. & $\begin{array}{l}\text { LKPD matematika dapat menuntun saya dalam } \\
\text { memahami materi pelajaran vang di sampaikan }\end{array}$ & 5 & 5 & 5 \\
\hline & Rata - rata & 4,8 & 4,7 & 4,7 \\
\hline
\end{tabular}

Rata - rata hasil keseluruhaan penilaian kepraktisan LKPD oleh ketiga peserta didik terhadap LKPD yang dikembangkan, termasuk dalam kategori praktis dengan skor rata - rata sebesar 4,73 dikategorikan sangat baik, sehingga LKPD yang di kembangkan telah memenuhi kriteria kepraktisan. Untuk mengukur keefektifan LKPD, diberikan soal uraian materi segiempat (persegi panjang dan trapesium) dan segitiga pokok bahasan keliling dan luas.Tahap ini penilaian keefektifan LKPD diperoleh dari persentase ketuntasan tes peserta didik.Kriteria ketuntasan minimun (KKM) di SMPK St. Maria Assumpta Kupang sebesar 65.Hasil tes peserta didik sebanyak 27 orang, terdapat 21 peserta didik yang memperoleh nilai diatas nilai Kriteria Ketuntasan Minimun (KKM). Hasil penilaian keefektifan LKPD yangdiperoleh dari persentase ketuntasan tes peserta didik sebesar 77,7\% (dikategorikan baik), sehingga LKPD yang dikembangkan memenuhi kriteria keefeektifan.Pada penelitian pengembangan LKPD berbasis Etnomatematika pada materi Segiempat dan Segitiga telah 
memenuhi kriteria kualitas LKPD yang baik, karena memenuhi kriteria kevalidan, kepraktisan, dan keefektifan LKPD.Hasil penelitian ini menunjukan pengembangan lembar kerja peserta didik (LKPD) berbasis Etnomatematika pada materi segiempat dan segitiga memenuhi kriteria kevalidan, kepraktisan, dan keefektifan. Kualitas LKPD memenuhi kriteria kevalidan dengan skor rata-rata keseluruhan sebesar 4,8. Kualitas LKPD memenuhi kriteria kepraktisan dengan skor rata-rata keseluruhan sebesar 4,73 dan kualitasLKPD memenuhi kriteria keefektifan dengan persentase ketuntasan sebesar 77,7\%. LKPD berbasis Etnomatematika yang dikembangkan memenuhi kriteria kevalidan, kepraktisan, dan keefektifan sehingga memenuhi kriteria kualitas LKPD yang baik.Suatu produk dikatakan berkualitas jika memenuhi tiga kriteria yaitu validitas (validity), kepraktisan (practicality), dan keefektifan (effectiveness) (Nieveen, 1999). Penggunaan LKPD ini mendapat respon yang baik dari peserta didik karena mereka ikut terlibat aktif dalam proses pembelajaran. LKPD dapat mendorong proses proses berpikir peserta didik sehingga memudahkan peserta didik dalam menyelesaikan suatu masalah serta menumbuhkan proses berpikir pada diri peserta didik (Prabawati et al., 2019). Peserta didik tidak merasa bosan dan jenuh ketika belajar matematika (Susanti Esa, Sukasno, 2017). Dengan demikian, dalam proses pembelajaran hendaknya guru harus menggunakan media LKPD, agar guru dan peserta didik sama-sama terlibat aktif dalam proses pembelajaran.

\section{KESIMPULAN}

Pengembangan Lembar Kerja Peserta Didik (LKPD) berbasis Etnomatematika pada materi Segiempat dan Segitiga telah memenuhi kriteria kevalidan dengan rata-rata skor penilaian validator sebesar 4,80 dan respon peserta didik terhadap LKPD untuk mengetahui kepraktisan dengan skor ratarata keseluruhan sebesar 4,73 serta persentase ketuntasan tes peserta didik sebesar 77,7\% memenuhi kriteria keefektifan. Dengan demikian Pengembangan LKPD berbasis Etnomatematika pada materi segiempat dan segitiga ini berkualitas baik, sehingga LKPD ini layak untuk digunakan oleh peserta didik dalam proses pembelajaran dan diharapkan dapat meningkatkan keaktifan siswa dalam pembelajaran matematika.

\section{DAFTAR PUSTAKA}

Agustini, N. K. A., Leton, S. I., \& Fernandez, A. J. (2019). Studi Etnomatematika Pada Budaya Masyarakat Larantuka. Asimtot: Jurnal Kependidikan Matematika. https://doi.org/10.30822/asimtot.v1i1.95

Atika, N., \& MZ, Z. A. (2016). Pengembangan Lks Berbasis Pendekatan Rme Untuk Menumbuhkembangkan Kemampuan Berpikir Kritis Matematis Siswa. Suska Journal of Mathematics Education. https://doi.org/10.24014/sjme.v2i2.2126

Ayuningtyas, A. D., \& Setiana, D. S. (2019). Pengembangan Bahan Ajar Matematika Berbasis 
Etnomatematika Kraton Yogyakarta. Aksioma: Jurnal Program Studi Pendidikan Matematika. https://doi.org/10.24127/ajpm.v8i1.1630

Darmayasa, J. B., Wahyudin, W., \& Mulyana, T. (2018). Ethnomathematics: The use of multiple linier regression $\mathrm{y}=\mathrm{b} 1 \mathrm{X} 1+\mathrm{b} 2 \times 2+\mathrm{e}$ in traditional house construction Saka Roras in Songan Village. In Journal of Physics: Conference Series. https://doi.org/10.1088/17426596/948/1/012076

harionik Yeni, \& Yoga, budi bakty. (2018). Pengembangan bahan ajar lembar kerja siswa dengan pendekatan matematika realistik, $6(1), 40-55$.

Marsigit. (2016). PENGEMBANGAN PEMBELAJARAN MATEMATIKA BERBASIS ETNOMATEMATIKA.

Mustamin, S. H. (2017). Pembelajaran Matematika Dengan Pendekatan Realistik. Lentera Pendidikan: Jurnal Ilmu Tarbiyah Dan Keguruan, 20(2), 231-239. https://doi.org/10.24252/lp.2017v20n2i8

Nieveen, N. (1999). Prototyping to Reach Product Quality. In Design Approaches and Tools in Education and Training. https://doi.org/10.1007/978-94-011-4255-7_10

Pertiwi, I. J., \& Budiarto, M. T. (2020). Eksplorasi etnomatematika pada gerabah mlaten, 04(02), 438-453.

Prabawati, R., Yanto, Y., \& Mandasari, N. (2019). Pengembangan LKS berbasis PMRI menggunakan konteks etnomatematika pada materi spldv, 2(2), 73-79.

Purnamasari, K., \& Lestari, H. P. (2017). Pengembangan Perangkat Pembelajaran Untuk Smp Kelas VII Materi Segitiga Dan Segi Empat Melalui Pendekatan Kontekstual Dan Model Pembelajaran Probing Prompting. Jurnal Pendidkan Matematika.

Susanti Esa, Sukasno, R. R. (2017). Mahasiswa STKIP-PGRI Lubuklinggau Dosen STKIP-PGRI Lubuklinggau 1, 1-11.

Thiangarajan, Sivasailam, \& Dkk. (1974). thiangarajan,sivasailam,dkk (1974) instructional development for training teachers of exceptional children. (National center for improvment educational system, Ed.). washinton DC.

Wahyuni, A., Aji, A., Tias, W., \& Sani, B. (2013). P - 15 peran etnomatematika dalam membangun karakter bangsa, (November), 978-979. 